\title{
Introduction: China Question of Western Theory
}

\author{
Kang Liu \\ Duke University
}

Follow this and additional works at: https://docs.lib.purdue.edu/clcweb

(3)

Part of the Comparative Literature Commons

Dedicated to the dissemination of scholarly and professional information, Purdue University Press selects, develops, and distributes quality resources in several key subject areas for which its parent university is famous, including business, technology, health, veterinary medicine, and other selected disciplines in the humanities and sciences.

CLCWeb: Comparative Literature and Culture, the peer-reviewed, full-text, and open-access learned journal in the humanities and social sciences, publishes new scholarship following tenets of the discipline of comparative literature and the field of cultural studies designated as "comparative cultural studies." Publications in the journal are indexed in the Annual Bibliography of English Language and Literature (Chadwyck-Healey), the Arts and Humanities Citation Index (Thomson Reuters ISI), the Humanities Index (Wilson), Humanities International Complete (EBSCO), the International Bibliography of the Modern Language Association of America, and Scopus (Elsevier). The journal is affiliated with the Purdue University Press monograph series of Books in Comparative Cultural Studies. Contact:<clcweb@purdue.edu>

\section{Recommended Citation}

Liu, Kang. "Introduction: China Question of Western Theory." CLCWeb: Comparative Literature and Culture 22.5 (2020): <https://doi.org/10.7771/1481-4374.3819>

This text has been double-blind peer reviewed by $2+1$ experts in the field.

The above text, published by Purdue University Press @P Purdue University, has been downloaded 0 times as of 12/13/ 20.

This document has been made available through Purdue e-Pubs, a service of the Purdue University Libraries. Please contact epubs@purdue.edu for additional information.

This is an Open Access journal. This means that it uses a funding model that does not charge readers or their institutions for access. Readers may freely read, download, copy, distribute, print, search, or link to the full texts of articles. This journal is covered under the CC BY-NC-ND license. 


\section{PURDUE}

U N I V E R S I T Y UNIVERSITY PRESS < http://wWW.thepress.purdue.edu>

\section{CLCWeb: Comparative Literature and Culture}

ISSN 1481-4374 <http://docs.lib.purdue.edu/clcweb> Purdue University Press @Purdue University

CLCWeb: Comparative Literature and Culture, the peer-reviewed, full-text, and open-access learned journal in the humanities and social sciences, publishes new scholarship following tenets of the discipline of comparative literature and the field of cultural studies designated as "comparative cultural studies." In addition to the publication of articles, the journal publishes review articles of scholarly books and publishes research material in its Library Series. Publications in the journal are indexed in the Annual Bibliography of English Language and Literature (Chadwyck-Healey), the Arts and Humanities Citation Index (Thomson Reuters ISI), the Humanities Index (Wilson), Humanities International Complete (EBSCO), the International Bibliography of the Modern Language Association of America, and Scopus (Elsevier). The journal is affiliated with the Purdue University Press monograph series of Books in Comparative Cultural Studies. Contact: <clcweb@purdue.edu>

Volume 22 Issue 5 (December 2020) Article 1

Kang Liu,

"Introduction: The China Question of Western Theory"

<http://docs.lib.purdue.edu/clcweb/vol22/iss5/1>

Contents of CLCWeb: Comparative Literature and Culture 22.5 (2020)

Special Issue The China Question in Western Theory. Ed. Liu Kang

<http://docs.lib.purdue.edu/clcweb/vol22/iss5/>

Abstract: In his article, "The China Question of Western Theory," Kang Liu formulates the China Question of western theory as both western critical frameworks to understand the rise of China, and how these critical frameworks present China not only as an object of study but also as a question intrinsic to contemporary cultural and social theories. The essays in this special issue address the China Question of western theory in multilinear, multivalent ways: first, the Chinese reception and appropriation of western theory; second, the western reception and appropriation of Chinese theory, namely Maoism, and third, the Chinese reception and re-appropriation of those western theories that reinvented and appropriated Chinese theory. 


\section{Kang LIU}

\section{Introduction: The China Question of Western Theory}

The "China Question" refers to both critical frameworks to understand the rise of China, and how these critical frameworks, derived largely from western experiences of modernity, present China not only as an object of study but also as a question intrinsic to contemporary cultural and social theories. As the explanatory adequacy of current theories and models is increasingly called into question when addressing China-related issues, it is imperative to engage in international collaborative research with scholars from China and across the world. This special issue's essays are based on papers presented at the Workshop on the China Question of Cultural and Media Studies, October 4-5, 2019 at Duke University and then the follow-up Symposium of Conversations between Civilizations: the China Question of Western Theory, December 13-14, 2019 at Wuhan University. It is a continuation of the discussion broached in CLCWeb's special issue on Rethinking Critical Theory and Maoism, 20.3 (2018).

The essays in this issue focus on the discursive formation of modern Chinese literary theory and criticism during the PRC period (1949-present) in terms of the reception, appropriation, and transformation of western theories that lay the foundation of the discipline and institution of art and literary studies in modern China. The China Question of Western theory is both extraneous and immanent in terms of its objects and methodology. Though extraneous to China, Western theories and the questions they arouse, once appropriated and transformed in China, can turn into modes of inquiry intrinsic in Chinese intellectual thinking and academic research. This has been especially true during the last four decades of gaige kaifang (reform and opening up) in China, in which "translating and borrowing" and "addressing Chinese issues with Western discourses" have become the predominant modes of both intellectual inquiry and political decision and policy making.

From the end of the 1990s to the present, neo-Marxist critical theory and a garden-variety of "post-isms"-poststructuralism, postmodernism, and postcolonialism-have been translated, borrowed, and appropriated in China en masse and become dominant critical discourse in Chinese academe. These more recent years contrast sharply with the decade of the 1980s, or the so-called Chinese cultural reflection movement. Chinese intellectuals then passionately embraced Western ideas from the late nineteenth and early twentieth centuries, translating works of Sigmund Freud, Friedrich Nietzsche, Friedrich Hayek, Martin Heidegger, Ludwig Wittgenstein, Jean-Paul Sartre, Susan Sontag, the New Critics, and so forth.

A few salient features of the historical context for the Chinese reception of Western theories should be noted. First, the brief yet historic period of the 1980s Chinese cultural reflection movement unleashed a heteroglossia of ideas, to borrow Mikhail Bakhtin's concept. Massive modern EuroAmerican ideas, both liberal and conservative, opened up new ways of thinking about Chinese modernity, which threatened to subvert the powerful leftist tradition that has legitimated the Chinese Communist Party (CCP)'s rule. Second, the Marxist and leftist orthodoxy in China, though largely scorned and rejected by Chinese intellectuals in the 1980s, provided fertile ground for the reception of neo-Marxist and leftist Western theories in the new millennium. Third, a more assertive and increasingly nationalist China, especially during the recent years, called forth renewed efforts for Chinese exceptionalism vis-à-vis Western universalism. Since Western literary theories, be they leftist, liberal, or conservative, are lumped together under the rubric of Western ideas, they have become the targets of CCP-sanctioned campaigns against universalism. However, these assaults on universalism cause great anxiety and consternation, especially among those who have dedicated themselves to the translation, dissemination, and appropriation of Western theories which they must now denounce.

For Western theory, on the other hand, "China" is conceived as a singular question, or a problematic, as the Other, exterior to its conceptual framework. Meanwhile, the China Question as such is ineluctably internalized in Western theory, as an immanent part of the western universalist thinking of subjectivity, social formations and (post-)modernity. The China Question is not only practical and empirical, but theoretical, too, in that "China" is sometimes at the theoretical core of Althusserian high theory, in the guise of Maoism, which, in its multiple incarnations, is itself an invention of the western theoretical edifice. Meantime, Maoism inspired various kinds of Third World, anti-colonial insurgencies, which in turn can be traced to western connections, in cases such as Khmer Rouge's chieftain Pol Pot, whose Parisian education in the 1960s exposed him to Mao's insurrectional radicalism. Neo-Marxist and left-leaning Western theories, however, when translated and reappropriated in China, transmogrified into an array of neo-leftist academic discourses that not only 
replicate the highly abstract, esoteric rhetoric of western sources, but also obliquely reaffirm, in one way or another, Maoist overtones.

The essays in this special issue address the China Question of western theory in multilinear, multivalent ways: first, the Chinese reception and appropriation of western theory; second, the western reception and appropriation of Chinese theory, namely Maoism, and third, the Chinese reception and re-appropriation of those western theories that reinvented and appropriated Chinese theory. These three circular movements of theories are not chronologically ordered. The first one is more comprehensive, and covers much longer periods from the late nineteenth century to the present. The second, the western reception of Chinese theory, overlaps with the first chronologically, but is much more limited in scale. The third, the Chinese re-appropriation, has been an on-going trend over the last twenty years, and is a multi-directional intersection or interface that the majority of essays try to tackle in this issue.

The authors of the essays are scholars from China, mostly working in the field of literary and cultural studies. Their essays showcase some current critical work in the Chinese academe, as our authors are quite active in China, publishing profusely in Chinese-language scholarly periodicals. Most of the essays were first written in Chinese, then translated to English, and adapted and modified to befit the norms and styles of English-language academic writings. Their Chinese versions, on the other hand, have either been published or are ready for publication. Such a project that simultaneously engages both English- and Chinese-language scholarly communities is needed for the task of exploring the China Question of western theory in bilateral, and bilingual, if not multi-lingual fashion. Granted, there are many scholars conversant bilingually in these academic communities, and insofar as a large array of theoretical works are available in English, lack of Chinese language proficiency is not a serious obstacle for conversations on our subject matter. However, the authors featured here do offer some Chinese perspectives stemming from their lived experiences and feelings in the current Chinese environment that careful readers may decipher thorough their expositions in plain and somewhat restrained academic language.

It must be added that the essays' translation, adaptation, or in most cases re-writing in English, was an excruciating process. At the beginning, the translated versions were practically unreadable, filled with theoretical jargon and adjectives, in the tortuous, winding syntax of a Pidgin English or Chinglish. We (the authors, their English translators and I myself) then worked together over and over again, and came to realize that the problem lies not so much in the technical hurdles of translating Chinese to English as in the Chinese versions themselves. Simply put, our authors write in a Chinese academic language that has been seriously affected by translations of western theoretical works, a kind of Europeanized "Pidgin Chinese," a hybrid Chinese bearing the foreign accents of RussianGerman-English-French, in terms of grammar, syntax, stylistics and phraseology. When this kind of hybrid writing in translated style, or with strong foreign accent, so to speak, is re-translated back into a source language, that is, English, the result is a tangled mess. Then the tactic we adopted was to have authors re-write the Chinese versions in a simple and plain style, largely free from jargon and obscurant abstraction, and then render them in equally simple, plain and accessible English--the essays' English quality is for the readers to judge, but we have at least done our due diligence. It turns out that the genealogy of such a linguistic hybridity of academic discourse is in itself a significant part of the China Question of western theory. Translations between European languages may not have such an acute syntactic and stylistic disparity, although English tends to be less stylistically winded in academic writing than, say, Russian and German (which influenced Chinese political-academic discourse immensely via massive translations of the works of Lenin, Stalin, other Soviet theorists, and Marx and Engels). When translating completely different languages, such as between Chinese and European languages, mistranslation and misinterpretation are bound to arise. And the kinds of latent syntactic, stylistic impacts between source and target languages that we encounter here are actually affecting our mode of thinking and writing in more profound ways than simple linguistic misuse.

While we may explore the translation question on other occasions, the current issue primarily addresses the traveling theory in multi-directional and circular ways. Zeng Jun's essay discusses the impacts of western Marxism on Chinese literary studies during the early years of the PRC, an eastward journey of western theory that began in the late nineteenth century, only this time under the new regime, with a new mission. Zeng delineates the profiles of three Marxist theoretical entities, namely western Marxism, Soviet Marxism, and Chinese Marxism. Their distinction lies primarily in their political functions. Whereas western Marxism in capitalist western Europe and North America has largely been confined to academic circles with the exception of the 1960s global upheavals when neoMarxist and left-wing intellectuals took to the street and joined public protests, Marxism in the Soviet Union had been, until its demise, and in China today still is, the dominant ideology of the party-state 
or the Ideological State Apparatuses (ISAs). Much of the China Question, with respect to western Marxism, arises from the fundamentally different political functions that various kinds of Marxisms have assumed. Yan Fan's essay on an Althusser-Machiavelli-Mao lineage (sometimes Gramsci creeps in), explores the conceptual transaction of Mao's notion of "the people/the masses" in Althusser's writings from the 1960 s to 1980s. Yet the critical difference in political functions of Althusser's and Mao's theories, arising from concrete historical conditions, is missing in Yan's discussion. Li Wei, however, picks up on this crucial missing link in her brilliant symptomatic reading of Mao's conceptualization of the "national form" and reinvention of "the people" and "New China" that later inspired Althusser and other French Maoists. Grounded squarely in historical evidence, Li convincingly extracts from Mao's theoretical writings as well as the political, ideological campaigns Mao launched during the Yan'an period (1937-45) a new way of imagining China under the rubrics of Chinese Marxism, with a lasting impact on China today.

Li Song's essay examines the genealogy of Chinese literary theory in the PRC in terms of MoscowYan'an-Beijing Modes through analysis of state-sanctioned textbooks of literary studies. Yang Jiangang, in a similar vein, investigates the political policies and statements in arts and literature in the PRC (1949-present) from the perspective of discursive formations and statements. Their essays exercise historicizing and meta-critical analyses of the formations of Marxist literary theory in China, from Mao era (1949-76) to the present, or the last four decades of Reform. Politics and political functions of theory underscore Li's and Yang's narratives, drawing on methodological insights from Althusser, Gramsci, and Foucault. The lingering Soviet influence in China's ideological arena, highly visible in literary theory and criticism, is often neglected by western China Studies. Li and Yang break some new ground in this regard.

The next four essays focus on theoretical currents in China now, especially postcolonial theory with considerable popularity in Chinese academe. Wu Yuyu examines the impact of postcolonial theory in China on the question of nation and nationalism, focusing on Chinese appropriations of Jameson, Said, and Bhabha. The entanglement of postcolonialism with the questions of "nation" and "nationalism" are as much a principal China question as a global question, as nationalism and popularism, under the guises of, and from various political spectrums of the extreme Trump-style 'alt-right" to radical leftist identity politics, have polarized the world, and severely undermined globalization. Lu Xinyu's essay is an adapted, abridged translation of her much longer Chinese essay published in 2015 that received considerable critical attention, a relentless rebuttal of an assortment of U.S.-based views on Chinese cinema, from "Sinophone" to "Chinese-language cinema." Lu's critique zeros in on the issue of PRC's cinematic representation of ethnic minorities, which obviously relates to a much larger condition of existence of ethnic minorities in China, now and then, in terms of political policies as well as cultural and ideological representations. We have agreed to keep the essay's argument as it is, and hope the subject matter that Lu's essay deals with will open up some space for further conversations about the current conditions and questions. Wu Zhijie's essay is a critical analysis of the postcolonial translation theory popular in China, particularly that of Lawrence Venuti and André Lefevere. His essay, however, broaches the question of translation under the specific conditions of the China Question of western theory, an important initial attempt toward the exploration of translation as a central problematic that we hope to embark on later. Li Hui's essay does not discuss postcolonialism, but instead traces the history of "traversing," or the mistranslation and misappropriation of the theories of Culture Industry, cultural industries, and creative industries, etc. since the Reform era, revealing how the misreading of western theories are indicative of Chinese cultural and ideological trends and policy shifts.

The next two essays, by Zhu Zhirong and Li Qingben respectively, deal with the China Question not in terms of contemporary theoretical debates, but by going much further back to the historical legacies of the late nineteenth and early twentieth centuries. Zhu's essay examines the formation of modern historical studies of traditional Chinese literature and literary criticism in terms of its interaction with and transformation of western theory. His meticulously documented and well-argued essay reaffirms the historical legacy of "Eastward Movement of Western Ideas" and the formation of literary theory and criticism as a new discipline of classical Chinese studies since the beginning of the twentieth century, drawing on western "scientific" method, that is, systematic studies of literary histories, genres, forms, and devises. Li, on the other hand, proposes, by way of Said's "circle model," a "circular journey" of literary texts and theories from ancient China to the West and then back to modern China, through rereading Ezra Pound's imagism which, inspired by classical Chinese poetry, ended up influencing Chinese modernism. What Zhu and Li tell us in their narratives is that, under the current circumstances when nationalistic, xenophobic, and exceptionalist fervor tends to overshadow our critical inquiries, we should not forget the fundamental question of the meaning of literature and 
arts and the mission of literary theory and criticism, and that we should adopt a well-reasoned yet historically grounded mindset, as evinced by Zhu's and Li's essays.

Finally, we invite the veteran Chinese literary theorist Zhu Liyuan to write a response to J. Hillis Miller's exchange with him in Modern Language Quarterly (2018) in which I also participated, on issues of digital culture and hermeneutics. Zhu Liyuan's narrative of the Chinese controversies over Miller's alarmist notion of the end of literature and arrival of the digital age aroused Miller's interest, and in his commentary on three Chinese critics' works, he devotes most space responding to Zhu's account. This essay is Zhu's response to Miller's response, in a different venue. Zhu adds a new section, critiquing Miller's binarism of poetics and hermeneutics, which is not part of the earlier $M L Q$ exchanges. Zhu goes over at length the western considerations of poetics and hermeneutics from Aristotle to Gadamer, contending that literary form and content are as one, and that the poetics and hermeneutics that Miller sometimes considered to have separate functions all deal with content and form. In today's English-speaking community of literary studies, politics and ideology of form and content are the order of the day, which would quite likely remind veteran Chinese scholars such as Zhu Liyuan of the heydays of the Cultural Revolution, when radical politics and ideologies reigned supreme and literary forms and content were all subservient to class struggle. We, of course, find no such traces of concern in Zhu's essay. Instead, he ends his essay by saying "I'm hopeful that many more scholars would join us in such conversations, which undoubtedly boost modern transformation of classical Chinese literary theory and criticism, as an integral part of world literary theories and criticisms in diverse, heterogenous, and multiple configurations." We echo his sentiments.

Author profile: Liu Kang is visiting professor at Nanjing University of Information and Technology, China, and professor of Duke University. He is an Elected Member of Academia Europaea (The Academy of Europe) since 2015. $\mathrm{He}$ is the author of twelve books, and written widely in scholarly journals in both English and Chinese. His research ranges from contemporary Chinese media and culture, globalization, to Marxism and aesthetics. Email: <liukang@duke.edu>. 